\title{
Ellos también vienen
}

Keywords: vacaciones; viajar; hoteles; animales

Las vacaciones plantean, para la mayoría de los que convivimos a diario con animales de compañía, una cuestión de logística a veces difícil de resolver. ¿Vienen o no vienen con nosotros de vacaciones?.

Viajar con animales de compañía es en España un problema, por la falta de facilidades con las que nos encontramos los que hacemos turismo doméstico. Si el desplazamiento con nuestros perros, gatos, etc, se realiza en transporte propio, la única cuestión es proveerse de los elementos necesarios (agua fresca, bebedero, arnés, correa, algún juguete o premio con el que se puedan distraer) y, desde luego, hacer paradas regularmente que, aparte de para descansar de la conducción, les permitan hacer sus necesidades. No voy a recordar aquí la importancia de no dejarlos dentro del coche, por el peligro de que sufran un golpe de calor, eso lo sabemos todos. En cambio, si tenemos que utilizar el transporte público, empieza un mar de dificultades. En la web tenemos recogidas y actualizadas la normativa que a este propósito existe [1], por lo que me remito, en caso de dudas, a que se lea detalladamente cuanto allí se dice [2] . El resultado es algo desalentador y la pregunta que surge es, si la legislación vigente, está orientada a facilitar que los animales de compañía viajen con nosotros, o, más bien, está orientada a hacernos desistir de la idea. Me inclino por la segunda opción, aunque con la seguridad de que tiene que cambiar y no tardará mucho en hacerlo.

Cuestión aparte es el alojamiento. Son aún excepción los establecimientos hoteleros que aceptan a animales de compañía en España, pero, he de decir -en honor a la verdad-, que, los que los aceptan, dan todo tipo de facilidades. Con el tiempo, he recopilado algunas direcciones -que no me importa compartir [3]-, donde siempre hemos sido bien recibidos; por dicha razón, volvemos. A este respecto, hay que saber que no existe una normativa unificada en España; los establecimientos hoteleros aceptan o no animales de compañía en sus dependencias, como consecuencia del derecho de admisión que les asiste, lo que en algunos casos, en efecto, se hace constar en la normativa local o autonomica pertinente, bajo la mencion de prohibiciones relativas a los animales, en concreto en establecimientos publicos. Prohibiciones que, evidentemente, no afectan a los perros-guia.

Cuando se alude -como justificación para rechazar a los animales de compañía en un hotel-, una supuesta normativa sanitaria, que impide aceptar a los animales en el establecimiento, conviene saber que dicha normativa es inexistente. Por lo tanto, es una cuestión de cultura, de hábitos, de ver la situación de un viajero con un animal de compañía como algo normal [4]. Los animales de compañía entre nosotros, como fenómeno urbano, son algo relativamente reciente. Viajar con ellos, es aún poco frecuente. Sin embargo, si dirijimos nuestra mirada a nuestro entorno europeo, la situación es precisamente la inversa. En toda centroeuropa los viajeros con animales de compañía, son, por regla general, bien recibidos en transportes, hoteles, restaurantes y bares. Es más, no es sorprendente que, cuando aprieta el calor, ofrezcan un bebedero con agua fresca para el animal de compañía, que se situa plácidamente sentado bajo la mesa. Hay mil experiencias que se podrían contar, en este sentido.

Emprender un viaje con nuestro animal de compañía es una aventura fascinante. Les encanta venir. El rito -al menos en nuestro caso-, empieza cuando ven que aparecen las maletas. Recuerdo a uno de mis perros que, en cuanto abría la maleta sobre la cama para hacer el equipaje, en un descuido, se metía dentro y me miraba con una expresión de dicha desarmante. Para tranquilizarle, sacaba su bolsa y la ponía en un lugar bien visible. No paraba de darle vueltas, de darle empujones con el hocico, se sentaba encima, hasta conseguir que metiera también sus cosas. 
Albergo la esperanza de que la futura legislación europea sobre animales de compañía, fije algunos estándares en esta materia también [5]. Mientras tanto, me parece que tendríamos que promover un movimiento con el slogan: ELLOS TAMBIEN VIENEN, o parecido. Todos saldríamos ganando.

LA EDITORA

Teresa Giménez-Candela Catedrática de Derecho Romano

Animal Law Profesor

Universitat Autònoma de Barcelona

[1] Vid. En la Base de datos, bajo la voz "Transporte publico".

[2] Solo a titulo de ejemplo, puede verse la prohibición de animales domesticos en transportes publicos de León, “La Ordenanza Municipal reguladora de la tenencia de perros y otros animales domesticos”, en su art. 11 ; asi como la de Valencia, “Ordenanza Municipal de la ciudad de Valencia sobre tenencia de animales", en su art. 6

[3] Entre otros: La Hosteria del mar, en Peñiscola; el Hotel Meson del Cid, en Burgos; el Hotel Convento Las Claras, en Peñafiel ; el Balneario Caldes de Boi.

[4] La web de la Fundacion Affinity ofrece un listado actualizado de hoteles y casas rurales que admiten perros, en su " Guia para viajar con animales 2011".

[5] Por ahora, vid. Regulation of the EC No 998/2003. 